\title{
Chapter 8 \\ Securing Indigenous Dispossession Through Education: An Analysis of Canadian Curricula and Textbooks
}

\author{
Laura Schaefli, Anne Godlewska, and Christopher Lamb
}

\section{Introduction}

The beliefs and attitudes that were used to justify the establishment of residential schools are not things of the past: they continue to animate official Aboriginal policy today. Reconciliation will require more than apologies for the shortcomings of those who preceded us. It obliges us to recognize the ways in which the legacy of residential schools continues to disfigure Canadian life and to abandon policies and approaches that currently serve to extend that hurtful legacy (Truth and Reconciliation Commission of Canada, 2015, pp. 103-104).

We also have no history of colonialism. So we have all of the things that many people admire about the great powers but none of the things that threaten or bother them. (Former Prime Minister Stephen Harper (2006-2015) presenting to the G20 summit in Pittsburgh on September 25, 2009; quoted in Wherry, 2009).

In the quotations above, we hear two views of reality: an Indigenous view of Canada as a colonial country with a powerful legacy of destructive policies toward Indigenous peoples; and a state view of Canada as an innocent place, untouched by colonialism. ${ }^{1}$ The contrast is even more striking as Prime Minister Stephen Harper is the prime minister who in 2008 apologized for the harm inflicted on Indigenous people by Residential Schools, a more than 100-year policy of forced removal of Indigenous children from their families for placement in under-resourced schools dedicated to the assimilation of Indigenous children-in short, a colonial project. How can such contradictions exist within a society and within a single mind? As we

\footnotetext{
${ }^{1}$ We use the term Indigenous as an umbrella term for all people in Canada who identify as such, including First Nations, Métis, and Inuit. We use the term Aboriginal in legal contexts and in the context of Newfoundland and Labrador, where it is the favored term.
}

\footnotetext{
L. Schaefli $(\bowtie) \cdot$ A. Godlewska $\cdot$ C. Lamb

Department of Geography and Planning, Queen's University, Kingston, ON, Canada

e-mail: godlewsk@queensu.ca
} 
know, denial and continued support for the violence that is colonialism takes work. The ideologies supporting colonialism - the myths of a hierarchy of civilizations, the white man's burden, and the vanishing Indian — and the imaginative geographies of spatial exclusion have resulted from sustained intellectual and cultural labor (Battiste, 2013; Fitzmaurice, 2007, 2014; Moreton-Robinson, 2015; Williams, 1990). Intellectuals, authors, artists, bureaucrats, educators, and everyday citizens, working on multiple levels in society, conceive and carry out these efforts. Working together, these ideologies and their purveyors are a powerful force. However, as we argue in this chapter, it is the formal education system that plays the most important role, through its cultivation of colonial epistemes-entire ways of understanding the world and one's place in it. Our examination of curricula and texts in three provinces in Canada-Newfoundland and Labrador, Ontario, and British Columbiasuggests that in all three educational jurisdictions, students are learning a logic of relation premised on the disappearance of Indigenous peoples as sovereign, selfdetermining nations. Silence around Indigenous philosophies and territories, apologia for colonial incursions on Indigenous territories, and reinforcement of racialized hierarchies of being all work to minimize colonial violence and preclude imagination of distinct, vital, and self-determining Indigenous nations. Particularly troubling are the ways in which curricula and texts invite students to participate in the perpetuation of colonial modes of thought and action.

We have carried out research in three jurisdictions: Newfoundland and Labrador, in the far east of the country-Ontario, in the center and the region that holds the nation's capital - and British Columbia, in the far west. These regions are fundamentally different in terms of the Indigenous peoples of the territories, the physical geography of the provinces, their history of colonial settlement, and the degree and nature of engagement between Indigenous peoples and settlers. Newfoundland and Labrador was the first region to encounter European colonialism. It was also the last to join the Confederation of Canada. When it did so in 1949, it failed to recognize the existence of Aboriginal peoples within the province, including Mi'kmaq, Innu, and Inuit (Hanrahan, 2003). Ontario, formerly Upper Canada, was the heart of the British colony and ultimately the nation's economic and political center, instrumental in developing and implementing colonial policies including the Indian Act and residential schools (Lawrence, 2004; Milloy, 1999). In British Columbia, in contrast to many other parts of Canada, the provincial and federal governments did not sign treaties with Indigenous peoples, preferring to force them onto tiny reserves which governments and settlers proceeded to erode over time and in a variety of ways (Harris, 2002). Since the 1990s, the provincial and federal governments have sought to negotiate modern treaties, with the aim of securing the forms of political and economic certainty attractive to capital investment. However, many First Nations in the province have refused to take part, given government denial of Indigenous sovereignties and insistence on conversion of collectively held lands to fee simple title. For these reasons, relations between Indigenous and non-Indigenous people in British Columbia are perhaps more unsettled than elsewhere in Canada.

As a first step to our contribution to decolonizing college and university curricula, we have analyzed the curricular documents and the textbooks used in primary 
and secondary education in all three jurisdictions. We were interested in the degree to which students were undergoing colonial or decolonizing education and what strategies of inclusion or exclusion these educational systems deploy. Our research to date has shown that these educational systems are all colonial and work to marginalize Indigenous peoples, though they employ subtly different strategies of exclusion. As members of a colonial society and as non-Indigenous academics, we cannot escape colonial thinking. Thus, we began by educating ourselves through reading critical Indigenous theorists and by working closely with Indigenous educators and community members. Part of our research, which is not presented here, has involved the development of knowledge tests for entering and exiting postsecondary students. It is through codesigning the knowledge tests that we have gained insight into what colonialism and a decolonized society might look like. This process has informed our word-by-word and multidisciplinary analysis of curricular documents and textbooks across these three provinces of Canada. ${ }^{2}$

\section{Minimizing Colonial Violence}

\section{Vanishing Indigenous Sovereignties and Critical Perspectives}

Curricula and textbooks in Newfoundland and Labrador, Ontario, and British Columbia all work to deny the violence of colonialism. A principal strategy is evacuation of Indigenous sovereignties from discussion of European arrival in what is now known as Canada. By omitting Indigenous territories, legal traditions, and critical perspectives, the curricula and texts assume European jurisdiction and encourage students to think about land as empty of Indigenous peoples. In Newfoundland and Labrador, whitewashing language works to minimize dispossession: Land acquisition resulted from "interactions between European and Aboriginal Peoples" (N.L.D.E., 2011a, p. 204). Reserves, the tiny remnants of Indigenous lands to which status Indians largely have been restricted, are "parcels of land set aside by the federal government for the exclusive use of a First Nation." There is no discussion of the federal government's right to that land, how reserves were created, the parcels' adequacy, or limited First Nations freedom to govern reserve land (Clark \& Wallace, 1996, p. 99). Texts in British Columbia similarly present the Canadian government as always already sovereign and generous, describing the reserve system with no attention to the coercion, betrayals, and violence they entailed (Deir et al., 2000; Francis, 2000; Sterling, 2000, 2002). This perspective consistently undermines Indigenous sovereignties: Colonists are portrayed as coming from "countries" and the places they colonize are "areas of land," always already "other" and "for" the colonizer (Clark \& McKay, 1992; Sterling, 2000, p. 143). In Ontario, curricula and texts work to vanish Indigenous sovereignties by framing settler history as the

\footnotetext{
${ }^{2}$ We analyzed curricula and associated textbooks in Newfoundland and Labrador up to 2013, in Ontario up to 2015, and in British Columbia up to 2016.
} 
totality of history. Indigenous traditional territories are never discussed. In fact, the closest mention of Indigenous territories in the entire K-12 curriculum is a parenthetical aside focused on contemporary populations: "[I]llustrate and explain the regional distribution patterns of various peoples across Canada (e.g., Aboriginal peoples, Francophones, immigrant groups)" (OME, 2005a, p. 31). When Indigenous peoples are discussed, the focus is on settler benefit (OME, 2004, p. 34). Additionally, several high school history and civics texts frame Canada as developed exclusively through British and French democratic traditions (Blair, 2003; Brune \& Bulgutch, 2000; Clark \& Wallace, 2003, p. 176; Gini-Newman, 2001, p. 6), which is a formulation also present in British Columbia's curricula and texts (BCME, 1997, p. 26; Buckingham, Marcotte, Epp Buckingham, Manning, \& Thompson, 1997, p. 19). One Ontario text goes so far as to claim that it is only now that Indigenous people are healthier and better educated that they are "beginning to make their mark in Canada" (Gini-Newman, 2001, p. 394). Such patronizing portrayal neglects the pivotal roles of Indigenous people(s) and political philosophies in shaping the governance of New France, British North America, and Canada, a characterization that perpetuates terra nullius (empty land) logic, casts Indigenous peoples as passive nonagents, and thereby reinforces assumptions of settler dominance (Borrows, 2010; Brooks, 2008; Delâge \& Sawaya, 2001; Sawaya, 2002).

\section{Denying Colonialism in Canada}

Curricula and texts further minimize colonial violence by underplaying, or denying outright, the presence and endurance of colonialism in Canada. In Newfoundland and Labrador, this denial is achieved principally by framing Indigenous people as settlers "like everyone else," a dynamic that works to undermine any claims by Indigenous people rooted in prior presence. At least two of the textbooks used by most students, the Grade 5 text and the high school Newfoundland and Labrador Studies text, contend that, as Aboriginal people in Newfoundland and Labrador migrated at some time to what is now Newfoundland from the mainland, they are not indigenous to the territory. The Grade 5 text (Cram \& Fizzard, 1991, Chapter 3) teaches students that both earlier and later Aboriginal people were all settlers. In the high school Newfoundland and Labrador Studies text, science, in the form of archaeological evidence and cartographic display, is harnessed to frame Aboriginal peoples as "immigrants" like "all residents of Newfoundland and Labrador" (Newfoundland and Labrador Department of Education, 2010, p. 114). The text does include a sidebar critique of this contention by Daniel Ashini (Innu), but the main part of the text critiques his assertions, letting the students know how they should be thinking about any claims to prior presence (Newfoundland and Labrador Department of Education, 2010, p. 123). Also in this text, assertions of early Mi'kmaq presence (Martijn, 2003, p. 121) are dismissed as tainted by the existence of disputes over land rights-disputes which are not assumed to taint the perspective of non-Indigenous players. The link between archaeological data and 
nationalist discourse, and the weakness of archaeological data unsupported by ethnographic and sociological research and evidence, is not discussed (Kristensen \& Davis, 2015, pp. 524-526; Smith \& Wobst, 2005). Nor is the political nature of cartography (Brealey, 1995; Sparke, 1998). The argument that all people living in what is now Newfoundland and Labrador are ultimately settlers also works to convert treaty obligations from rights to privileges. One of the high school Canadian geography texts makes explicit the association of Aboriginal people with privileges (Cartwright, Birchall, \& Pierce, 1996). Without nuance or reference to treaty obligations, the text describes "Indians" on reserves as non-tax paying (p. 294) and asserts that "tuition as well as travel and living expenses" are provided for all "aboriginal students for the first four years of post-secondary education" (p. 297). Using this strategy, non-Indigenous people can disregard centuries of dispossession and cultural and personal assault, even though the perception of Indigenous privileges is belied by the statistics on Indigenous disadvantage in Canada.

In Ontario, the principal strategy of colonial denial is silence, which, together with silence around Indigenous traditional territories, works to legitimate contemporary Canadian political formulations that dissociate Indigenous peoples from political and economic self-determination. The word colonialism is never used in the curriculum. Instead, the arrival of Europeans is referred to as contact, settlement, or migration (OME, 2004, 2005a, 2005b). Texts present exploration as an exclusively European phenomenon that constituted the first major expansion of human horizons (Asselstine, 2000c, p. 51), was an inevitable outcome of the heroic pursuit of knowledge (Francis, 2000, p. 56), and is inherently exciting and fun (Asselstine, 2000a, p. 22, 2000b, p. 134). Other texts present colonialism as natural, inevitable, and ubiquitous, invoking the Bering Strait theory of Indigenous migration to argue that ultimately, Indigenous peoples are settlers too, as in Newfoundland and Labrador (Asselstine, 2000b, p. 10; Busato \& Takacs, 2002b, p. 209; Smith \& Pelech, 2002, p. 2). Still others are entirely silent about the presence, endurance, and consequences for Indigenous traditional governance of legislated racism including the Indian Act and residential schools. At the same time, curricular directives frame Indigenous peoples as one amongst many ethnic minorities to be accommodated in a multicultural society, and cast government as an innocent and benevolent arbiter of Aboriginal rights. For example, students are required to "identify contributions to Canada's multicultural society by regional, linguistic, ethnocultural, and religious communities (e.g., Aboriginal peoples, Franco-Ontarians, Métis, Black Canadians, Doukhobors, Mennonites, local immigrant communities)" (OME, 2005a, p. 55). In this multicultural framework, the sovereignty of the Canadian state is taken as given and conflicts around land, resources, and cultural continuity are reduced to a matter of majority rule (Bannerji, 2000; Coulthard, 2014; Lawrence \& Dua, 2005; Razack, 1998). The existence and diversity of Indigenous legal traditions are disavowed, and the government and multicultural rhetoric are presented as innocent of alignment with assimilative interests.

Curricular documents and textbooks in British Columbia deny the existence of colonialism in two principal ways: by representing colonialism as a phenomenon Canada moved beyond as it emerged from colonial status, and as a problem of else- 
where. Only three of the mandatory social studies curricular documents mention colonialism and the titles and organization of these courses relegate colonialism to the past. The thematic organization of Grade 5's "Canada from Colony to Country" (BCME, 2006a) portrays Canada as emerging from British and French colonialism to autonomous nationhood, free of colonialism. Primarily concerned with the "development of the nation," this course recounts resource exploitation in British Columbia, the building of the Canadian Pacific Railway, and the establishment of Canadian Confederation. None of the content makes any direct reference to colonialism. This theme is repeated in Grade 10's "Canada from 1815 to 1914," where students learn to analyze "British support for colonial independence," as one of the "factors that led to Confederation and to the development of Canada's provinces and territories" (BCME, 2006b, p. 27).

Only in the Grade 9's "Europe and North America from 1500 to 1815" are students expected to "define colonialism, imperialism, and nationalism," and to "analyze effects of colonialism on trade and conflict" in Canada, yet the discussion is limited to the period up to 1815, ignoring ongoing colonial presence (BCME, 1997, pp. 26, 28). Beyond representing colonialism as a past event, the curricula and texts in British Columbia present it as a problem of elsewhere. The secondary-school text "Canada Revisited" (Social Studies 9) limits its discussion to British and French colonialism and policy (Clark \& McKay, 1992, p. 80). In "Across the Centuries" (Social Studies 8), "Greeks established colonies along the coast of Italy in 750 B.C.," and "[d]uring the 1800s, Europeans began to explore and claim land in Africa" (Armento, 1994, p. 469). Here colonialism "runs its course" during the 1900s in Africa, colonies in the "Western Hemisphere" having "won their independence in the 1700s and early 1800s" (p. 469). The History 12 curriculum and texts focus only on "colonial rule" in "Palestine and the Indian subcontinent" and "decolonization of India and Indochina" (BCME, 2006c, pp. 31, 33-34). Sustained and coherent discussion of colonialism in Canada is restricted to optional courses, available to students in their last 2 years of study, which few students take. Social Justice 12 does suggest coverage of the "continuing legacy of colonialism and its effects on Canada's Aboriginal peoples in contemporary Canadian society" (BCME, 2008, p. 40), and British Columbia First Nations Studies 12 includes significant coverage of contemporary colonialism in British Columbia with a focus on "the resistance of First Nations people to colonialism, especially land encroachment" (BCME, 2006d, p. 5). However, only around $2 \%$ of students in the province take either of these courses each year as opposed to, for instance, the 14\% taking History 12 or the 13\% taking Law 12 (BCME, 2016, 2017; Lamb, 2015). The relegation of meaningful discussion of colonialism in Canada to optional courses so infrequently taken by students subtly reinforces the representation of colonialism as "a problem of elsewhere;" topics related to colonialism in Canada are framed as "fringe" content peripheral to the "mainstream." In the British Columbia curricula and texts, colonialism apparently happened long ago and far away. 


\section{Reinforcement of Racialized Hierarchies of Being}

Curricula and texts across all three provinces work subtly to legitimate colonial interests by invoking racialized hierarchies of being. Relegating Indigenous peoples to the past is a common strategy. In Newfoundland and Labrador, the curriculum and texts describe the original inhabitants of the island of Newfoundland, the Beothuk, as extinct, even though Beothuk blood is present in the general population and the Beothuk and the Innu of Labrador are closely related (Macleod \& Brown, 2005, p. 27; N.L.D.E., 2005, pp. 34, 125). Commonly used in Newfoundland and Labrador to describe the Beothuk, the word extinct places all the Indigenous people of Newfoundland and Labrador, including the Mi'kmaq, in an absolute past. The use of the term extinct is important in other ways: As its common usage is for plants and animals, the term places the Beothuk in that realm of being. Further, most people think of extinction as an unfortunate by-product of the incursion of agriculture, resource extraction, and industrial activity into formerly undeveloped or economically inactive areas. The word, then, fits neatly into two other formulations in the curriculum and texts: Indigeneity as inherently contradictory of modernity and Indigenous people as not part of the economy. Firmly ensconcing Indigenous peoples in noneconomic realms denies the history, presence, and relationships of Indigenous peoples in and with their lands and thus effectively turns Indigenous lands into "wastelands of non-achievement," ripe for potential settlement and development by settlers (Fitzmaurice, 2007, 2014; wa Thiong'o, 1986, p. 3). The portrayal of Indigeneity as contradictory to modernity appears early on, in the Grade 5 curricular directive "[Aboriginal people] want to progress in the modern world but they also want to preserve their traditional way of life" (N.L.D.E., 2012, p. 59). The key word in this assertion is but, which creates a contradiction. Language linking Indigenous people to "primitivism" is pervasive in the texts: Indigenous peoples use tools; the Europeans use equipment (Cram \& Fizzard, 1991, pp. 44, 194), and Indigenous people are always present before European arrival but rarely possess continuity. Absence from the economy appears in the curriculum and in Canadian geography texts, which take a chronological approach to the demography of the country that begins with Indigenous peoples but makes no further mention of First Nations, Métis or Inuit peoples when discussing immigration, urbanization, resources, energy, economics, globalization, finances, trade, or culture (Clark \& Wallace, 1996). The high school economics text reinforces this by relegating Aboriginal people to reserve lands, poverty and "a traditional economy" (Bolotta, Hawkes, Mahoney, \& Piper, 2002). The portrayal of Indigeneity and economy as mutually exclusive reinforces discourses of social progression that demand Indigenous assimilation into contemporary economic and social life. The sense of hierarchy with non-Indigenous people at the top and Indigenous people at the bottom is encapsulated in the frequent use of the possessive, "our Aboriginal people" (N.L.D.E., 2011b, p. 57), "our forests" (Cram \& Fizzard, 1991, p. 194), and "our culture" (N.L.D.E., 2007, p. 105), which combined reinforce the sense that nonAboriginal Canadians own everything, including the Indigenous people. 
Curricula and texts in Ontario also work to reinforce racialized hierarchies of being, but do so by portraying Indigenous peoples as nonexistent, past, or weak. As early as Grade 3 and continuing into high school, maps and other geographic strategies insinuate that Indigenous peoples and contemporary land title do not exist in the southern Canadian provinces (Bisset \& Permanand-Collins, 2004, p. 38; Clark, Wallace, \& Earle, 2006, p. 203; Cruxton, 2008; Gutsole \& Gutsole, 1998, p. 6). Textbooks as early as Grade 5 portray Indigenous worldviews as static and irrational and Indigenous cultures as legitimate insofar as they adhere to pre-European contact practices. Change, it is implied, is antithetical to Indigeneity (Asselstine, 2000a, p. 158, 2000b, p. 10; Busato \& Takacs, 2002b, p. 253; Draper, Andrew, Duncan, \& Roth, 2006, p. 161; Gini-Newman, 2001, p. 13; Smith \& Pelech, 2002, p. 2). Still other texts portray Indigenous peoples as technologically unsophisticated, a framing that works to legitimate colonialism by casting European technologies as a gift (Busato \& Takacs, 2002b, p. 189; Gini-Newman et al., 2000, p. 303; Healy, 2003, p. 150). Moral claims about government and the nature of Indigenous rights are also mobilized in Ontario textbooks in ways that naturalizes the authority of the Canadian state. Texts consistently portray government as benevolent and generous with regard to Indigenous rights, yet are silent about the instrumental work of Indigenous leaders and activists in advancing protection of those rights. At the same time, Indigenous struggles for self-determination are presented as irrational, criminal, and opportunistic. This appropriation and negative characterization of Indigenous struggle is deeply racialized, constituting a "possessive investment" in the goodness of white Canadians that serves to rescue "settler innocence" while undermining critiques that illuminate the contours and mechanisms of systemic racism and colonialism (Lipsitz, 2006, p. 1; Srivastava, 2005; Tuck \& Yang, 2012, p. 1). As early as Grade 5 , textbooks frame prejudice as a historical phenomenon that has been addressed successfully in contemporary times by government initiatives (Clark et al., 2006; Draper et al., 2006, p. 63; Francis, 2000, p. 34). Other texts describe contemporary Canadians and their government as enlightened benefactors who have moved beyond colonialism and racism. A Grade 10 history text relegates racism to the past and excuses it, stating that "the racist attitudes toward Aboriginal people led many immigrants to believe they were doing something positive for these people." The text then lauds the inclusion of Aboriginal and treaty rights in the 1982 Constitution with no discussion of the sustained efforts of Indigenous leaders to advance that inclusion (Gini-Newman, 2001, p. 41). A Grade 9 text takes a similarly congratulatory approach, praising "Canadians and their government" for realizing "that the Aboriginal people of Canada have been treated unfairly over the centuries." The same text makes no mention of the work of Indigenous leaders and activists to challenge assimilative policies (Clark et al., 2006, p. 204). Still other texts are more explicit in their undermining of Indigenous people and rights. Some texts present the evacuation of Indigenous self-determination as a foregone conclusion: "[G] overnment treaties deprived Aboriginal peoples of the right to govern themselves" (Clark et al., 2006, p. 201); Indigenous peoples "lost their ability to control their own destiny" (Healy, 2007, p. 189). Others present Aboriginal rights as inherently criminal. A Grade 11 Law text places discussion of Aboriginal and treaty rights in a 
chapter on "Defenses for the Accused" and warns students that "there are times when Aboriginal peoples may argue that they have an Aboriginal or treaty right to act in a way that would be illegal for anyone else" (Blair, 2003, p. 263). A Grade 10 Civics text considers that Canadian governments "have signaled their willingness to give Aboriginal communities more control" but "they always have a bottom line...Aboriginal peoples must respect the laws of this country and the rights of its non-native citizens" (Brune \& Bulgutch, 2000, p. 147). One text even implies that inequities do not really exist, reinforcing the portrayal of Indigenous people as untrustworthy: "Many workers, such as visible minorities, women, aboriginal people, and people with disabilities, have already adjusted to [new] employment situations, whether by choice or necessity ... and thus have a subtle advantage" (Busato \& Takacs, 2002b, p. 79). Textbooks' portrayal of racism and colonialism as past, Canadians and their government as inherently benevolent, and Indigenous people and rights as criminal and untrustworthy work to obfuscate the existence of and reasons for Indigenous resistance while dissuading critical thought about systemic racism and colonialism.

\section{Inviting Students to Model Colonial Dispossession}

Curricula and texts sometimes invite students to model colonial dispossession, either under the guise of designing sound social policies for Indigenous people or just as an exercise. In Newfoundland and Labrador, the clearest example of such an exercise can be found in a high school Geography text, "Contact Canada" (Cartwright et al., 1996), in which students learn the stages of development of a fictitious land, Innuvial, and map the terrain (pp. 288-294). In a chilling re-enactment of relocation tragedies that rocked Inuit in the Eastern Arctic through much of the twentieth century (Royal Commission on Aboriginal Peoples, 1996; Tester \& Kulchyski, 1994), the textbook asks students to relocate the fictitious Innuviat so that their location makes more sense in the Canadian economy. A Grade 8 Ontario textbook likewise encourages the development of assimilative policies, inviting students to develop proposals detailing the steps the Brazilian government could take to encourage the Yanomami to "leave their traditional technology behind so that they can take advantage of better health care and deal with outsiders coming onto their land" (Busato \& Takacs, 2002a, p. 173). In these exercises, students appear to be being prepared to assume the mantle of colonialists: bureaucrats who make decisions for and about Indigenous people, on the basis of statistics, maps, and general principles, in the name of economic and social advancement with no on-the-ground knowledge, no accountability to Indigenous people, and no consciousness of the violence relocation entails.

Some of the most troubling normalizations of colonial dispossession in British Columbia curricula and textbooks occur in activities where curriculum and text direct teachers to ask students to inhabit imaginatively the role of colonizer. The Social Studies 9 curriculum portrays colonialism and imperialism as adventurous 
and exciting when students are to "compare the exploration mandate given to Captain James Cook with that of the charter of the starship Enterprise, focusing on reasons for exploration" (BCME, 1997, p. 28). It is worth noting that the fictional Federation embraces a policy of do no harm/do not interfere, which is a far cry from the realities of colonialism on Earth. Yet the curriculum does not use the Star Trek comparison to make this point. Students learn to identify with the colonizers when asked to become a colonizer for a day and develop their own "charters." Many of the exercises in the texts also treat Indigenous peoples as a problem to be managed. An exercise in the secondary-school text "Across the Centuries" (Social Studies 8) asks students to imagine how they would "establish a colony for [their] country," including how they would "manage the colony" and what they would do if "natives already lived on the site" (Armento, 1994, p. 470). The Social Studies 9 text "Canada Revisited" includes an exercise in which students are to "prepare an official report for the British government outlining your point of view regarding what you think should become part of British policy on what to do with the Native peoples" (Clark \& McKay, 1992, p. 81). The geographical focus of many exercises draws on and reinforces colonial notions of land and resources. An exercise in the Grade 4 text "Islands" encourages students to imagine the type of island they would choose to live on, and then "build a model" (Peturson, Asselstine, \& Luks, 1996, p. 47). For this exercise students start from scratch and populate their island as they see fit, an activity uncomfortably similar to the colonial European perspective of land in North America as terra nullius (Fitzmaurice, 2007, 2014; Pateman \& Mills, 2007). Grade 5 takes this treatment even further in a fascinating exercise that ties together physical geography, natural resources, and settlement patterns. Students must "work in groups to design an island," to make maps, "name the region of Canada where their island could be found," and "write a diary or journal entry of the first settler on the island and the discovery of a resource on the island that could sustain the development of a community" (BCME, 1997, pp. 177-178). In order to "assess the role of geographical factors in the development of trade and settlement in Canada and other colonies" the Grade 9 curricula challenges students to "design real estate advertisements to attract settlers to New France" and encourages them to "consider what features would attract prospective settlers" (BCME, 1997, p. 30). None of these exercises includes mention of Indigenous peoples and all three encourage insensitivity to the consequences for Indigenous peoples.

\section{Implications}

It is possible to track the affective consequences of the curricula and texts' colonial ideologies in student's imagination and words. We have surveyed 1st-year university students in Newfoundland and Labrador, measuring their knowledge against their social attitudes, where they were taught, what they think of what they were taught, and how they identify themselves. In that survey, prior to administering a knowledge test, we asked students to "name three things" they knew about 
Aboriginal people (Godlewska, Schaefli, Massey, Freake, \& Rose, 2017). Over 40\% of respondents chose Indigenous absence from the recent Canadian past, the Canadian present, and certainly from any Canadian future as what they know about Indigenous peoples. In spite of the fact that Indigenous people have long been the fastest growing demographic in Canada (Statistics Canada, 2005), in spite of significant Indigenous work and success in securing land and resource rights and in transforming the Canadian political landscape (Asch, 1984; Asch \& Macklem, 1991), and in spite of national attention in the form of apologies for wrongs committed (CBC News Canada, 2008), for far too many of these students Indigenous people are simply gone, not there, vanishing, or insignificant in number and culture. These students' voices eloquently echo the "Vanishing Indigenous sovereignties and critical perspectives" purveyed in texts and curricula and reflected in sustained Canadian political and legal strategies (Borrows, 2017):

- "A dying culture" (respondent 34, score 14\%);

- "They are dying off" (respondent 43, score 39\%);

- "There are very few 100\% aboriginal people living" (respondent 47, score 18\%);

- "They are an at risk demographic" (respondent 52, score 21\%);

- "Very few in Canada today" (respondent 70, score 18\%);

- "Their traditional way of life is being lost through assimilation" (respondent 75, score $27 \%$ );

- "People came in and took their land, gave them diseases, and killed them" (respondent 84, score 25\%);

- "Their culture is near but gone" (respondent 109, score 9\%);

- "We almost genocided them. We assimilated them to the point where there culture almost doesn't exist anymore" (respondent 157, score 34\%);

- "They were killed off by the white man" (respondent 249, score 32\%);

- "They were kicked out of Canada, All the aboriginal's were killed, and they fought hard for the land" (respondent 250, score 11\%).

While over $40 \%$ of the students who took the time to respond to our question expressed this "Vanishing Indian" myth, only $8 \%$ of the 1st-year students surveyed at Memorial University recognized that the Indigenous population of Canada is increasing, suggesting that the myth of absence is deeply embedded in young people's imaginations.

Quantitative results from our survey of over 40,000 1st-year students at 10 Ontario universities likewise reveal a prevailing misconception that wherever Indigenous people are, they are not here, not present, and by implication not relevant to students' daily lives or to Canadian society. It is significant, given the Canadian government's commitment to resource extraction and the disproportionate impact of that extraction on Indigenous people(s) (Cameron \& Levitan, 2014; Preston, 2013), that students have little understanding of Indigenous land and resource rights. Students are also substantially ignorant of Indigenous presence around them. Although about a third of students have some awareness of the Indigenous nations in Ontario, over 96\% cannot name the Nation(s) upon whose traditional territory their university campus is built. Moreover, despite the fact that 
the Indigenous population is not only growing but is the fastest growing population in Canada, fully $65 \%$ of Ontario students believe the Indigenous population is decreasing. When students are aware of Indigenous presence at all, the majority associate that presence with First Nations reserves, even though at least $70 \%$ of First Nations people in Canadian provinces live off reserve and reserves are not applicable to Métis and Inuit (Statistics Canada, 2013). Students' ignorance of the extent and importance of Indigenous traditional territories, their relegation of Indigeneity to reserves, and their conviction of Indigenous decline is deeply political: Ignorance of Indigenous presence, either here and now, or in resource extraction, for example, means that they cannot have the imagination to engage respectfully with Indigenous people on issues of major importance to all people in Canada today.

While we have not yet completed surveys with students in British Columbia, the prevailing discourse in the curricula and texts we have analyzed subtly reinforces a representation of Indigenous people in the province and country as disappearing and absent. This representation finds its foundation in the frequent use of sanitized and passive language, removing colonists and governments from the action and subtly absolving them of responsibility in dispossessing Indigenous peoples. "Many of the treaty lands were absorbed" (Cranny, Jarvis, Moles, \& Seney, 1999, p. vii); "Everywhere (Aboriginal people) were being forced out of good farmland" (p. 10); "It was believed that Aboriginal Peoples would disappear, either by being assimilated or by dying from diseases" (Deir et al., 2000, p. 347). Such passive language also naturalizes the development of colonial legal and economic structures. Settlers' "farms grew bigger and bigger." There "were also new laws about fishing and chopping down trees" (Sterling, 2000, pp. 43, 177). "Hunting land disappeared." "Native fishing rights vanished" (Peturson, Asselstine, \& Luks, 1997, p. 39). Reading colonialism as a neutral and inevitable process of history insinuates Indigenous absence, exonerates colonial actors and their actions, and obscures settlers' relationship and responsibility to any kind of future conciliation.

\section{Conclusion}

It is very clear that there is more commonality in approach to Indigenous peoples across the provinces than difference. Provinces separated by thousands of kilometers all engage their students in minimizing colonial violence, reinforcing racialized hierarchies of being, and practicing dispossession. It is indeed probable that such strategies are pancolonial, extending into Australia, South Africa, and the many nations shaped by settler colonialism (Veracini, 2010; Wolfe, 2006). Yet there are important differences that speak to the particular challenge of settler existence in each place. Jurisdiction in settler colonies has always been fragile, especially in resource-dependent settler colonies (Smandych, 2013). In Canada, all marginalizing strategies are ongoing attempts to assert settler control, particularly over territory and resources, because Canada has always been overly reliant on resource extraction. This reliance has been acute in Newfoundland and Labrador, creating 
economic vulnerability and political marginality vis-à-vis the national core areas. The "we are all settlers" narrative, perhaps given verisimilitude by the Beothuk extinction narrative and the relatively recent entry of Newfoundland and Labrador into Canadian Confederation (1949), frames all people in the province as marginalized while obfuscating Indigenous land and resource rights that the resourcedependent province frames as complicating potential future resource development. The "we are all settlers" narrative captures something of the myopia and inability to imagine a healthier society created by the economic vulnerability of a people on the edges of a country that has often neglected them. British Columbia, another heavily resource-dependent economy, has, thanks to the land eviction strategies long employed by the Federal and Provincial governments, such a politically active Indigenous population that any "we are all settlers" argument would seem immediately absurd, even to the myopic. In both British Columbia and in Newfoundland and Labrador, the curricula and texts construe resources and settler need as demanding Indigenous dispossession, which must be practiced. Encouraging students to think like colonists is a long-term strategy for clearing the land of Indigenous people. Ontario, the seat of Federal government, seeks to imagine all of the diverse and feuding parts of Canada as assimilated into the Canadian national imaginary. It is not surprising, then, that multiculturalism, which minimizes difference while apparently acknowledging it, is a preferred tool for Indigenous assimilation in the Ontario curricula and texts.

\section{References}

Armento, B. J. (1994). Across the centuries. Boston: Houghton Mifflin.

Asch, M. (1984). Home and native land: Aboriginal rights and the Canadian constitution. Vancouver, Canada: University of British Columbia Press.

Asch, M., \& Macklem, P. (1991). Aboriginal rights and Canadian sovereignty: An essay on R. v. Sparrow. Alberta Law Review, 29(2), 498-517. Retrieved from https://www.albertalawreview.com/index.php/ALR/article/view/1571/1560

Asselstine, L. (2000a). Tapestry 4. Toronto, Canada: Harcourt Canada.

Asselstine, L. (2000b). Tapestry 5. Toronto, Canada: Harcourt Canada.

Asselstine, L. (2000c). Tapestry 6. Toronto, Canada: Harcourt Canada.

Bannerji, H. (2000). The dark side of the nation: Essays on multiculturalism, nationalism and gender. Toronto, Canada: Canadian Scholars' Press.

Battiste, M. (2013). Decolonizing education: Nourishing the learning spirit. Saskatoon, Canada: Purich.

BCME (British Columbia, Ministry of Education, Analysis and Reporting). (2017, August 21). Class size by grade. Retrieved from British Columbia, Data Catalogue Website: https://catalogue.data.gov.bc.ca/dataset/class-size-by-grade

BCME (British Columbia, Ministry of Education, Skills and Training). (1997). Social studies 8 to 10: Integrated resource package 1997. Retrieved from http://www.bced.gov.bc.ca/irp/pdfs/ social_studies/1997ss810.pdf 
BCME (British Columbia, Ministry of Education). (2006a). Social studies K to 7: Integrated resource package 2006. Retrieved from http://www.bced.gov.bc.ca/irp/pdfs/social_ studies/2006ssk7.pdf

BCME (British Columbia, Ministry of Education). (2006b). Social studies 10: Integrated resource package 2006. Retrieved from http://www.bced.gov.bc.ca/irp/pdfs/social_studies/2006ss10. pdf

BCME (British Columbia, Ministry of Education). (2006c). History 12 integrated: Resource package 2006. Retrieved from http://www.bced.gov.bc.ca/irp/pdfs/social_studies/2006history.pdf

BCME (British Columbia, Ministry of Education). (2006d). BC first nations studies 12: Integrated resource package 2006. Retrieved from http://www.bced.gov.bc.ca/irp/pdfs/social_ studies/2006bcfns12.pdf

BCME (British Columbia, Ministry of Education). (2008). Social justice 12: Integrated resource package 2008. Retrieved from http://www.bced.gov.bc.ca/irp/pdfs/social_ studies/2008socialjustice12.pdf

BCME (British Columbia, Ministry of Education). (2016). Provincial required examinations-2015/16: Province_public and independent schools combined. Retrieved from http:// www.bced.gov.bc.ca/reports/pdfs/exams/req/prov.pdf

Bisset, E., \& Permanand-Collins, A. (2004). Discovering communities. Don Mills, Canada: Oxford University Press.

Blair, A. (2003). Law in action: Understanding Canadian law. Toronto, Canada: Prentice Hall.

Bolotta, A., Hawkes, C., Mahoney, R., \& Piper, J. (2002). Economics now: Analyzing current issues. Don Mills, Canada: Oxford University Press.

Borrows, J. (2010). Canada's indigenous constitution. Toronto, Canada: University of Toronto Press.

Borrows, J. (2017). Challenging historical frameworks: Aboriginal rights, the trickster, and originalism. The Canadian Historical Review, 98, 114-135. https://doi.org/10.3138/chr.98.1.Borrows

Brealey, K. G. (1995). Mapping them 'Out': Euro-Canadian cartography and the appropriation of the Nuxalk and Ts'ilhqot 'in First Nations' territories, 1793-1916. The Canadian Geographer/ Le Géographe Canadien, 39, 140-156. https://doi.org/10.1111/j.1541-0064.1995.tb00409.x

Brooks, L. T. (2008). The common pot: The recovery of native space in the Northeast. St. Paul, MN: University of Minnesota Press.

Brune, N., \& Bulgutch, M. (2000). Canadian by conviction: Asserting our citizenship. Toronto, Canada: Gage.

Buckingham, D. E., Marcotte, C., Epp Buckingham, J. L., Manning, B., \& Thompson, L. (1997). Learning about law. New York: McGraw-Hill Ryerson School.

Busato, L., \& Takacs, M. (2002a). Physical geography: Discovering global systems and patterns. Toronto, Canada: Gage Learning.

Busato, L., \& Takacs, M. (2002b). Human geography: Discovering global systems and patterns. Toronto, Canada: Gage Learning.

Cameron, E., \& Levitan, T. (2014). Impact and benefit agreements and the neoliberalization of resource governance and Indigenous-State Relations in Northern Canada. Studies in Political Economy, 93, 25-52. https://doi.org/10.1080/19187033.2014.11674963

Cartwright, F., Birchall, G., \& Pierce, G. (1996). Contact Canada. Don Mills, Canada: Oxford University Press.

CBC News Canada. (2008). Prime Minister Stephen Harper's statement of apology. Retrieved from http://www.cbc.ca/news/canada/ prime-minister-stephen-harper-s-statement-of-apology-1.734250

Clark, P., \& McKay, R. (1992). Canada revisited: A social and political history of Canada to 1911. Edmonton, Canada: Arnold.

Clark, B., \& Wallace, J. (1996). Canada: Land of diversity. Scarborough, UK: Prentice Hall Canada.

Clark, B., \& Wallace, J. (2003). Global connections: Canadian and world issues. Toronto, Canada: Pearson. 
Clark, B., Wallace, J. K., \& Earle, K. M. (2006). Making connections: Canada's geography. Toronto, Canada: Pearson Education.

Coulthard, G. S. (2014). Red skin, white masks: Rejecting the colonial politics of recognition. St. Paul, MN: University of Minnesota Press.

Cram, F., \& Fizzard, G. (1991). The Atlantic edge: Living in Newfoundland and Labrador. St. John's, Canada: Breakwater.

Cranny, M. W., Jarvis, G., Moles, G., \& Seney, B. (1999). Horizons: Canada moves west. Scarborough, UK: Prentice Hall Ginn Canada.

Cruxton, J. B. (2008). Flashback Canada. Toronto, Canada: Oxford University Press.

Deir, E., Fielding, J., Adams, G., Brune, N., Grant, P., Smith Abram, S., et al. (2000). Canada: The story of a developing nation. Toronto, Canada: McGraw-Hill Ryerson School.

Delâge, D., \& Sawaya, J. P. (2001). Les traités des Sept-Feux avec les Britanniques: Droits et pièges d'un héritage colonial au Québec [The Seven Fires Treaties with the British: Rights and traps of a colonial heritage in Québec]. Québec, Canada: Septentrion.

Draper, G., Andrew, W., Duncan, B., \& Roth, A. (2006). Geography now. Toronto, Canada: Thomson Nelson.

Fitzmaurice, A. (2007). The genealogy of Terra Nullius. Australian Historical Studies, 38(129), 1-15. https://doi.org/10.1080/10314610708601228

Fitzmaurice, A. (2014). Sovereignty, property, and empire, 1500-2000. Cambridge, UK: Cambridge University Press.

Francis, D. (2000). Outlooks 5: Connections Canada. Toronto, Canada: Oxford University Press.

Gini-Newman, G., Aitken, B., Eaton, D., Holland, D., Montgomery, J., \& Riddock, S. (2000). Canada: A nation unfolding (Ontario ed.). Toronto, Canada: McGraw-Hill Ryerson.

Godlewska, A., Schaefli, L., Massey, J., Freake, S., \& Rose, J. (2017). Awareness of indigenous peoples in Newfoundland and Labrador: Memorial's first year students (2013) speak. The Canadian Geographer, 61, 595-609. https://doi.org/10.1111/cag.12427

Gutsole, M., \& Gutsole, R. (1998). Discovering Canadian pioneers. Don Mills, Canada: Oxford University Press.

Hanrahan, M. (2003). The lasting breach: The omission of aboriginal people from the terms of union between Newfoundland and Canada and its ongoing impacts: Royal commission on renewing and strengthening our place in Canada. St. John's, Canada: Government of Newfoundland and Labrador.

Harris, R. C. (2002). Making native space: Colonialism, resistance, and reserves in British Columbia. Vancouver, Canada: University of British Columbia Press.

Healy, P. (2003). Canada travels: Issues and destinations. Toronto, Canada: Thomson Nelson.

Healy, P. (2007). Encounter Canada: Land, people, environment. Don Mills, Canada: Oxford University Press.

Kristensen, T. J., \& Davis, R. (2015). The legacies of indigenous history in archaeological thought. Journal of Archaeological Method Theory, 22, 512-542. https://doi.org/10.1007/ s10816-013-9190-7

Lamb, C. (2015). (Neo)liberal scripts: Settler colonialism and the British Columbia school curriculum. (Unpublished master's thesis). Kingston, ON: Queen's University

Lawrence, B. (2004). "Real" Indians and others: Mixed-blood urban native peoples and indigenous nationhood. Lincoln, NE: University of Nebraska Press.

Lawrence, B., \& Dua, E. (2005). Decolonizing antiracism. Social Justice, 32(4), 120-143. Retrieved from http://www.racialequitytools.org/resourcefiles/bonita-lawrence-decolonizing-anti-racism.pdf

Lipsitz, G. (2006). The possessive investment in whiteness: How white people profit from identity politics. Philadelphia, PA: Temple University Press.

MacLeod, M., \& Brown, R. (2005). Voyage to discovery: A history of Newfoundland and Labrador 1800-present. St. John's, Canada: Breakwater.

Martijn, C. (2003). Early Mi'kmaq presence in southern Newfoundland: An ethnohistorical perspective, c.1500-1763. Newfoundland Studies, 19(1), 44-102. Retrieved from https://journals. lib.unb.ca/index.php/NFLDS/article/view/141/239 
Milloy, J. S. (1999). A national crime: The Canadian government and the residential school system, 1879 to 1986. Winnipeg, Canada: University of Manitoba Press.

Moreton-Robinson, A. (2015). The white possessive: Property, power, and indigenous sovereignty. Minneapolis, MN: University of Minnesota Press.

Newfoundland and Labrador Department of Education. (2010). Newfoundland \& Labrador studies: Selected topics. St. John's, Canada: Government of Newfoundland and Labrador.

Newman, G. (2001). Canada: A nation unfolding. Toronto, Canada: McGraw-Hill Ryerson.

NLDE (Government of Newfoundland and Labrador, Department of Education). (2005). Social studies, grade 8, Newfoundland and Labrador history, interim edition, a curriculum guide. Retrieved from http://www.ed.gov.nl.ca/edu/k12/curriculum/guides/socialstudies/ gr8/Grade $\% 208 \% 20$ Newfoundland $\% 20$ and $\% 20$ Labrador $\% 20$ History $\% 20$ Curriculum $\% 20$ Guide\%20(2005).pdf

NLDE (Government of Newfoundland and Labrador, Department of Education). (2007). Social studies, grade 6, interim edition, curriculum guide. Retrieved from http://www.ed.gov.nl.ca/ edu/k12/curriculum/guides/socialstudies/socstudies_gr6.pdf

NLDE (Government of Newfoundland and Labrador, Department of Education). (2011a). Social studies, grade 9, interim edition, curriculum guide. Retrieved from http://www.ed.gov.nl.ca/ edu/k12/curriculum/guides/socialstudies/gr9/socialstudies_guide.pdf

NLDE (Government of Newfoundland and Labrador, Department of Education). (2011b). Social studies, Canadian history 1201, interim edition, curriculum guide. Retrieved from http://www. ed.gov.nl.ca/edu/k12/curriculum/guides/socialstudies/cangeog201202.pdf

NLDE (Government of Newfoundland and Labrador, Department of Education). (2012). Social studies, grade 5, interim edition, curriculum guide. Retrieved from http://www.ed.gov.nl.ca/ edu/k12/curriculum/guides/socialstudies/gr345/grade_5_social_studies_july_2012.pdf

OME (Ontario Ministry of Education). (2004). The Ontario curriculum: Social studies, grades 1 to 6; history and geography, grades 7 and 8. Toronto, Canada: Government of Ontario. Retrieved from http://www.ontla.on.ca/library/repository/mon/8000/244840.pdf

OME (Ontario Ministry of Education). (2005a). The Ontario curriculum grades 9 and 10: Canadian and world studies. Toronto, Canada: Government of Ontario.

OME (Ontario Ministry of Education). (2005b). The Ontario curriculum grades 11 and 12: Canadian and world studies. Toronto, Canada: Government of Ontario.

Pateman, C., \& Mills, C. W. (2007). Contract and domination. Malden, MA: Polity.

Peturson, R., Asselstine, L., \& Luks, N. (1996). Islands. Toronto, Canada: Harcourt Brace \& Company Canada.

Peturson, R., Asselstine, L., \& Luks, N. (1997). Freshwater trails. Toronto, Canada: Harcourt Brace \& Company Canada.

Preston, J. (2013). Neoliberal settler colonialism, Canada and the tar sands. Race \& Class, 55(2), 42-59. https://doi.org/10.1177/0306396813497877

Razack, S. H. (1998). Looking white people in the eye: Gender, race, and culture in courtrooms and classrooms. Toronto, Canada: University of Toronto Press.

Royal Commission on Aboriginal Peoples. (1996). The high arctic relocation: Summary of supporting information. Ottawa, Canada: Royal Commission on Aboriginal Peoples.

Sawaya, J. P. (2002). Alliance et dépendance: Comment la Couronne britannique a obtenu la collaboration des Indiens de la vallée de Saint-Laurent entre 1760 et 1774 [Alliance and dependence: How the British Crown obtained the collaboration of the Indians of the St. Lawrence Valley between 1760 and 1774]. Québec, Canada: Septentrion.

Smandych, R. (2013). Colonialism, settler colonialism, and law: Settler revolutions and the dispossession of indigenous peoples through law in the long nineteenth century. Settler Colonial Studies, 3, 82-101. https://doi.org/10.1080/18380743.2013.761937

Smith, J., \& Pelech, O. (2002). Discovering early civilizations. Don Mills, Canada: Oxford University Press.

Smith, C., \& Wobst, H. M. (2005). Indigenous archaeologies: Decolonizing theory and practice. One World Archaeology: Vol. 47. London, UK: Routledge. 
Sparke, M. (1998). A map that roared and an original atlas: Canada, cartography, and the narration of nation. Annals of the Association of American Geographers, 88, 463-495. https://doi. org/10.1111/0004-5608.00109

Srivastava, S. (2005). "You're calling me a racist?" The moral and emotional regulation of antiracism and feminism. Signs: Journal of Women in Culture and Society, 31, 29-62. https://doi. org $/ 10.1086 / 432738$

Statistics Canada. (2005). Projections of the Aboriginal populations, Canada, provinces and territories: 2001 to 2017 (Catalogue no. 91-547-XIE). Retrieved from https://www150.statcan. gc.ca/n1/en/catalogue/89-645-X

Statistics Canada. (2013). Aboriginal identity (8), age groups (20), registered or treaty Indian status (3), area of residence: On reserve (3) and sex (3) for the population in private households of Canada, provinces and territories, 2011 national household survey. In National household survey: Aboriginal peoples (Catalogue no. 99-011-X2011026). Retrieved from http://www12. statcan.gc.ca/nhs-enm/2011/dp-pd/dt-td/ap-eng.cfm?lang=e \&apath $=3 \&$ detail=0\&dim $=0 \& \mathrm{fl}=$ $\mathrm{a} \&$ free $=0 \& \mathrm{gc}=0 \& \mathrm{gid}=0 \& \mathrm{gk}=0 \& \mathrm{grp}=1 \& \mathrm{pid}=105401 \& \mathrm{prid}=0 \& \mathrm{ptype}=105277 \& \mathrm{~s}=0 \&$ showall $=0 \&$ sub $=0 \&$ temporal $=2013 \&$ theme $=94 \&$ vid $=0 \&$ vnamee $=\&$ vnamef $=$

Sterling, S. (2000). Outlooks 4: Our beginnings. Don Mills, Canada: Oxford University Press.

Sterling, S. (2002). Outlooks 3: Our communities. Don Mills, Canada: Oxford University Press.

Tester, F. J., \& Kulchyski, P. (1994). Tammarniit (mistakes): Inuit relocation in the Eastern Arctic, 1939-63. Vancouver, Canada: University of British Columbia Press.

Truth and Reconciliation Commission of Canada. (2015). What we have learned: Principles of truth and reconciliation. Winnipeg, Canada: Truth and Reconciliation Commission of Canada.

Tuck, E., \& Yang, K. W. (2012). Decolonization is not a metaphor. Decolonization: Indigeneity, Education \& Society, 1(1), 1-40. Retrieved from https://decolonization.org/index.php/des/ article/view/18630/15554

Veracini, L. (2010). Settler colonialism: A theoretical overview. Basingstoke, UK: Palgrave Macmillan.

wa Thiong'o, N. (1986). Decolonising the mind: The politics of language in African literature. Portsmouth, UK: Heinemann Educational.

Wherry, A. (2009). What he was talking about when he talked about colonialism. Retrieved from Macleans's (Toronto) Website http://www.macleans.ca/uncategorized/ what-he-was-talking-about-when-he-talked-about-colonialism/

Williams Jr., R. A. (1990). The American Indian in western legal thought: The discourses of conquest. New York, NY: Oxford University Press.

Wolfe, P. (2006). Settler colonialism and the elimination of the native. Journal of Genocide Research, 8, 387-409. https://doi.org/10.1080/14623520601056240

Open Access This chapter is licensed under the terms of the Creative Commons Attribution 4.0 International License (http://creativecommons.org/licenses/by/4.0/), which permits use, sharing, adaptation, distribution and reproduction in any medium or format, as long as you give appropriate credit to the original author(s) and the source, provide a link to the Creative Commons license and indicate if changes were made.

The images or other third party material in this chapter are included in the chapter's Creative Commons license, unless indicated otherwise in a credit line to the material. If material is not included in the chapter's Creative Commons license and your intended use is not permitted by statutory regulation or exceeds the permitted use, you will need to obtain permission directly from the copyright holder.

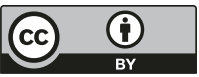

